\title{
RANCANG BANGUN SISTEM INFORMASI PENJUALAN PAKAIAN BERBASIS WEB PADA DISTRO CHANNEL CIREBON DENGAN METODE CRM OPERASIONAL (STUDI KASUS : DISTRO CHANNEL)
}

\author{
Cecep Juliansyah Abbas ${ }^{1}$ Ucup Sopyan $^{2}$, Dadan Nugraha ${ }^{3}$ \\ Fakultas Ilmu Komputer Universitas Kuningan \\ Jalan Tjut Nyak Dhien No. 36 A Cijoho Kuningan Jawa Barat 45513 Telepon (0232) 2875097
}

Email : cecepj.abbas@gmail.com ${ }^{1}$,ucupsopyan@gmail.com $^{2}{ }^{\text {dadan@ }} \underline{\text { uniku.ac.id }}^{3}$

\begin{abstract}
Distro Channel berlokasi di Jalan Raya Letjend S Parman,Pabuaran Cirebon. Pada saat ini, Distro Channel hanya memasarkan produknya di sekitar Pabuaran. Usaha untuk mendapatkan pendatang baru bergantung pada peran serta pelanggan lama untuk menyebarkan informasi mengenai Distro Channel kepada calon pelanggan lain. Hal tersebut menjadi kurang efektif dari segi waktu dan dapat mengakibatkan resiko kehilangan pelanggan menjadi lebih besar. Penelitian ini bertujuan untuk membuat sistem informasi yang menerapkan metode CRM operasional agar pelanggan dapat melakukan pembelian produk sesuai yang diinginkan dengan mengakses website Distro Channel. Penelitian ini menggunakan metode pengembangan sistem waterfall. Adapun tahapan dari waterfall ini ialah menganalisis kebutuhan sistem, membuat desain sistem, mengimplementasi sistem, melakukan pengujian serta pengoperasian dan pemeliharaan sistem. Implementasi dari CRM yang diterapkan pada Distro Channel yaitu pemberian poin sesuai dengan ketentuan akan mendapatkan 1 point untuk kelipatan belanja Rp. 65.000,-, poin dengan jumlah tertentu dapat ditukarkan dengan produk promo poin yang telah disediakan, poin tersebut bisa di gunakan sebagai potongan harga sebesar Rp.1.000,. Penerapan CRM dalam sistem ini diharapkan mampu meningkatkan pelayanan sehingga berimbas pada peningkatan loyalitas pelanggan.
\end{abstract}

Kata Kunci : Sistem Informasi, Distro Channel, CRM operasional, Waterfall, Website Penjualan, loyalitas pelanggan, poin.

Distro Channel is located on Jalan Raya Letjend S Parman, Pabuaran Cirebon. At this time, Distro Channel only markets its products around Pabuaran. Efforts to get new entrants depend on the participation of old customers to spread information about the Distro Channel to other prospective customers. This becomes less effective in terms of time and it can result in a greater risk of losing customers. This study aims to create an information system that implements operational CRM methods so that customers can make product purchases as desired by accessing the Distro Channel website. This research uses the waterfall system development method. The stages of this waterfall are analyzing system requirements, making system design, implementing system, testing and operating and maintaining system. The implementation of CRM that is applied in the Distro Channel, namely giving points in accordance with the provisions will get 1 point for multiples of spending Rp. 65,000, - points with a certain amount can be exchanged with the promo product points that have been provided, these points can be used as a discount of Rp. 1,000, -. The application of CRM in this system is expected to be able to improve services so that it impacts on increasing customer loyalty.

Keywords: Information Systems, Distribution Channel, operational CRM, Waterfall, Sales Website, customer loyalty, points.

\section{PENDAHULUAN}

Distro Channel adalah sebuah usaha yang bergerak dibidang penjualan pakaian laki laki maupun perempuan dengan gaya yang up to date, selain itu model yang di sesuaikan dengan perkembangan zaman terutama para remaja. Distro Channel berlokasi di Jalan Raya Letjend $\mathrm{S}$ Parman,Pabuaran Cirebon. Pada saat ini,
Distro Channel hanya memasarkan produknya di sekitar Pabuaran. Usaha untuk mendapatkan pendatang baru bergantung pada peran serta pelanggan lama untuk menyebarkan informasi mengenai Distro Channel kepada calon pelanggan lain. Hal tersebut menjadi kurang efektif dari segi waktu.

Selain itu dalam proses pemasaran yang dilakukan Distro Channel kurang 
JURNAL NUANSA INFORMATIKA

Volume 14 Nomor 1, Januari 2020

optimal karena masih menggunakan cara yang konvensional, diantaranya strategi periklanan masih dilakukan cara pemasangan spanduk di depan distro sehingga pelanggan yang diluar kota tidak dapat mengetahui informasi mengenai distro tersebut, pencatatan transaksi, stok barang dan laporaan masih menggunakan media kertas. Selain itu belum adanya pengelolaan terhadap pelanggan. Hal tersebut mengakibatkan resiko kehilangan pelanggan menjadi lebih besar. Proses penjualan pun terkendala jam operasional yang masih terbatas dari pukul 09.00 WIB sampai dengan pukul 21.00 WIB, serta wilayah penjualan masih di sekitar pabuaran saja sehingga mengakibatkan jumlah pelanggan yang tidak banyak.

Customer Relationship Management (CRM) adalah proses mengidentifikasi pelanggan, menciptakan customer knowledge, membangun customer relationship, dan membentuk persepsi pelanggan terhadap organisasi dan solusinya, CRM adalah proses mendapatkan, mempertahankan, dan mengembangkan pelanggan yang menguntungkan (profitable customers). Berdasarkan latar belakang masalah diatas, maka masalah yang akan dibahas pada penelitian ini adalah:

Bagaimana merancang dan membangun suatu website penjualan yang mampu memberikan informasi yang dibutuhkan pelanggan dan membantu pihak distro dalam pengelolaan transaksi?

Bagaimana menerapkan Metode CRM Operasional pada website Distro Channel dalam upaya pengelolaan pelanggan sehingga mampu meningkatkan loyalitas pelanggan terhadap Distro?

Adapun batasan masalah dalam membangun website penjualan pada Distro Cannel ialah membangun website penjualan yang dibuat meliputi pelayanan dan penjualan, menerapkan Customer Relationship Management (CRM) operasional dalam membangun website penjualan, pembayaran dilakukan dengan transfer antar bank dan pembeli harus mengupload bukti pembayaran, untuk setiap kelipatan Rp. 65.000,- mendapatkan 1 poin yang bisa ditukarkan ke produk
p-ISSN : 1858-3911, e-ISSN : 2614-5405

https://journal.uniku.ac.id/index.php/ilkom

promo poin yang telah di tetapkan dan bagi pelanggan yang mendapatkan poin dapat digunakan sebagai potongan harga sebesar Rp. 1.000,00,-.

Untuk itu perlu perubahan sistem penjualan yang dapat meningkatkan pelayanan dan dan tidak terbatas waktu dan wilayah. Sistem Informasi dapat membantu informasi yang akurat serta dapat melakukan pengelolaan dan pelayanan sehingga dapat meningkatkan loyalitas yang mampu mempertahankan pelanggan lama dan menarik pelanggan baru.

\section{METODE PENELITIAN}

\subsection{Waterfall}

Tahapan utama dari waterfall model langsung mencerminkan aktifitas pengembangan dasar. Terdapat 5 tahapan pada waterfall model, yaitu requirement analysis and definition, system and software design, implementation and unit testing, integration and system testing, dan operation and maintenance. [1]

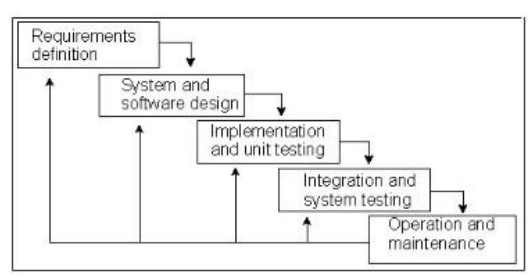

Gambar 1 Waterfall Model

Berikut adalah penjelasan dari tahapantahapan tersebut:

Requirement Analysis and Definition

Merupakan tahapan penetapan fitur, kendala dan tujuan sistem melalui konsultasi dengan pengguna sistem. Semua hal tersebut akan ditetapkan secara rinci dan berfungsi sebagai spesifikasi sistem.

\section{System and Software Design}

Dalam tahapan ini akan dibentuk suatu arsitektur sistem berdasarkan persyaratan yang telah ditetapkan. Dan juga mengidentifikasi dan menggambarkan abstraksi dasar sistem perangkat lunak dan hubungan-hubungannya.

Implementation and Unit Testing

Dalam tahapan ini, hasil dari desain perangkat lunak akan direalisasikan sebagai satu set program atau unit program. 
JURNAL NUANSA INFORMATIKA

Volume 14 Nomor 1, Januari 2020

Setiap unit akan diuji apakah sudah memenuhi spesifikasinya.

Integration and System Testing

Dalam tahapan ini, setiap unit program akan diintegrasikan satu sama lain dan diuji sebagai satu sistem yang utuh untuk memastikan sistem sudah memenuhi persyaratan yang ada. Setelah itu sistem akan dikirim ke pengguna sistem.

\section{Operation and Maintenance}

Dalam tahapan ini, sistem diinstal dan mulai digunakan. Selain itu juga memperbaiki error yang tidak ditemukan pada tahap pembuatan. Dalam tahap ini juga dilakukan pengembangan sistem seperti penambahan fitur dan fungsi baru.

Berdasarkan pengertian yang telah di jelaskan diatas dapat menghasilkan kesimpulan bahwa model waterfall adalah model yang dikembangkan untuk pengembangan perangkat lunak, membuat perangkat lunak. Model berkembang secara sistematis dari satu tahap ke tahap lain dalam mode seperti air terjun. Model ini melingkupi aktivitas-aktivitas sebagai rekayasa dan pemodelan sistem informasi, analisis kebutuhan, desain, koding, mengujian dan pemeliharaan.

Model pengembangan ini bersifat linear dari tahap awal pengembangan sistem yaitu tahap perencanaan sampai tahap akhir pengembangan sistem yaitu tahap pemeliharaan. Tahapan berikutnya tidak akan dilaksanakan sebelum tahapan sebelumnya selesai dilaksanakan dan tidak bisa kembali atau mengulang ke tahap sebelumnya.

\subsection{Customer relationship Management}

Konsep CRM bias dipahami dalam tiga level, yaitu:

\section{CRM Operasional}

Adalah proses otomatisasi yang terintegrasi dari keseluruhan proses bisnis yang berjalan di dalam perusahaan, baik penjualan maupun pemasaran. Pada proses ini meliputi customer touchpoint, frontback office dan integration.

Operasional CRM memberikan dukungan dalam proses bisnis, misalnya untuk penjualan, pemasaran dan layanan
p-ISSN : 1858-3911, e-ISSN : 2614-5405

https://journal.uniku.ac.id/index.php/ilkom

stafInteraksi dengan pelanggan biasanya disimpan di kontak pelanggan dan pelanggan dapat mengambil informasi yang diperlukan.Riwayat kontak dengan anggota staf menyediakan akses langsung ke pelanggan yaitu menyangkut informasi penting (produk yang dimiliki, sebelum mendukung panggilan dll),menghilangkan kebutuhan individual untuk mendapatkan informasi secara langsung dari pelanggan.

Aplikasi operasional CRM dibedakan menjadi tiga, yaitu:

a. Customer Facing Applications

Mencakup smua area dimana pelanggan berinteraksi dengan perusahaan Melalui cal center, help desk, otomatisasi servis dan lain-lain untuk menunjang penguunaan CRM, dapat digunakana sistern yang berbasis mobile web sehingga menjadi sarana sebagai Customer Interaction.

b. Customer Touching Applications

Disebut Customer Touching karena pelanggan berhubungan langsung dengan aplikasi sistem daripada berhubungan dengan perwakilan perusahaan. Pelanggan juga dapat membentuk self service support seperti mengecek sendiri status pesanan, urutan permintaan barang atau jasa, proses return barang atau jasa.

c. Customer-Centric Intelligence Applications

Menganalisis hasil proses operasi dan hasilnya digunakan untuk meningkatkan aplikasi CRM. Bagian dari Customer Intelegent antara lain adalah Data Warehouse sebagai pusat penyimpanan data baik data CRM maupun data non CRM.

\section{CRM Analytical}

Adalah proses analisis dari datadata yang dihasilkan melalui proses opersional CRM meliputi data mining.

3.CRM Collaborative

Adalah proses aplikasi kolaboratif pelayanan meliputi email,personalized, ecommunities, forum diskusi dan sejenisnya yang menyediakan fasilitas interaksi antara perusahaan dan pelangganya.[2]

\section{Business Process Reenginering}


JURNAL NUANSA INFORMATIKA

Volume 14 Nomor 1, Januari 2020

Business Process Rengineering merupakan suatu kegiatan yang harus dilakukan perusahaan dalam pengimplementasian proses baru. Mengidentifiaksi yang bertujuan untuk mengevaluasi kegiatan-kegiatan proses bisnis yang dimaksudkan apakah terdapat dampak dari kegiatan tersebut dalam menciptakan nilai tambah terhadap bisnis perusahaan.

Business Process Re-Enginering bisa dijadikan rekomendasi yang menghasilkan aplikasi Distro berbasis web yang mempu meningkatkan nilai tambah untuk Distro. [3]

\section{Flowmap Yang Diusulkan}

Berdasarkan analisa penulis tentang sistem yang sedang berjalan dengan beberapa kelemahannya, maka penulis menawarkan sebuah sistem penjualan yang baru, berdasarkan konsep yang sedang dijalankan dengan meminimalkan kelemahan pada sistem, sehingga dapat meningkatkan kualitas penjualan dan pelayanan pada Distro Channel kepada konsumen untuk lebih memudahkan dalam proses jual beli. Adapun konsep dari perancangan sistem penjualan yang penulis usulkan yaitu :

1. Sistem pelayanan untuk pelanggan baru dan lama diantaranya :

2. Pemberian point untuk transaksi kelipatan 65.000 mendapatkan 1 poin, poin tersebut dapat ditukarkan dengan barang yang telah disediakan.

3. Proses pengelolaan data produk, data pelanggan, data penjualan, dan pembuatan laporan penjualan seluruhnya dilakukan dengan sistem komputerisasi guna mempermudah dan mempercepat proses.

4. Dengan mengakses website Distro Channel maka secara otomatis calon pembeli akan dapat melihat informasi seputar Distro Channel.
p-ISSN : 1858-3911, e-ISSN : 2614-5405

https://journal.uniku.ac.id/index.php/ilkom

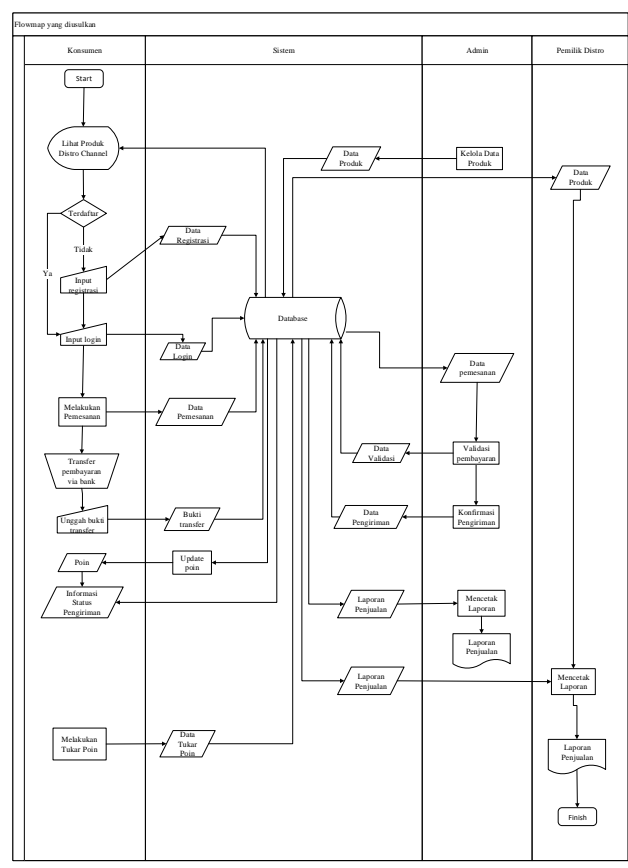

Gambar 2 Flowmap yang diusulkan

\section{Diagram Konteks}

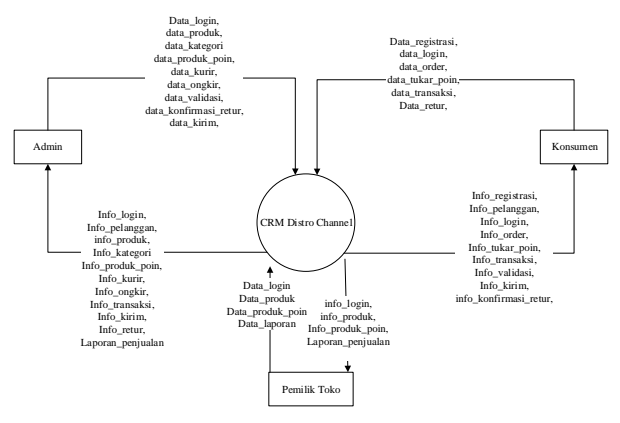

Gambar 3 Diagram Konteks

\section{DFD level 0}

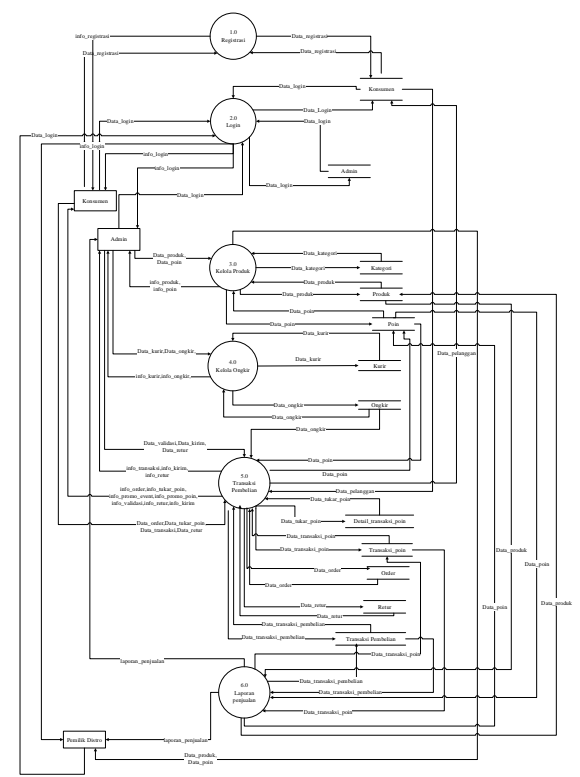

Gambar 4 DFD Level 0 
JURNAL NUANSA INFORMATIKA

Volume 14 Nomor 1, Januari 2020

\section{HASIL DAN PEMBAHASAN}

Implementasi sistem pada penelitian ini merupakan penerapan Customer Relationship Management pada perancangan sistem berbasis web untuk penjualan pakaian pada Distro Channel sehingga program atau aplikasi yang sesuai dengan tujuan pengembangan dan dapat digunakan. Implementasi sistem menjelaskan bagaimana sistem yang telah dibuat disesuaikan dengan perancangan yang telah disusun sebelumnya dan dapat berjalan sesuai dengan harapan.

\section{Halaman Home}

Halaman Home dibangun untuk menampilkan informasi awal mengenai penjualan pakaian yang ada di Distro Channel. Pada halaman ini semua pengguna dapat melakukan akses serta dilengkapi link, navigasi dan menu untuk mempermudah dalam melakukan akses data secara terbatas.

Halaman Home merupakan halaman default yang akan muncul pada saat pertama kali. Oleh sebab itu apabila terjadi kesalahan navigasi maka pengguna akan diarahkan pada halaman ini.

Bagian-bagian utama yang menyusun layout halaman beranda terdiri dari header, menu, isi konten berupa katalog pilihan pakaian dan footer. Pada bagian header terdapat judul web dan description yang menjelaskan nama Distro dan sejarah perusahaan.

Untuk lebih jelas mengenai tampilan halaman home yang telah dibuat dapat dilihat pada gambar 5 berikut ini.

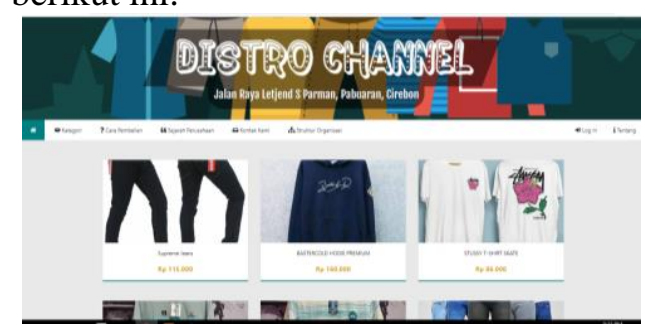

Gambar 5 Tampilan Halaman Home

Berdasarkan tampilan halaman Home pada gambar 5 di atas menunjukan bahwa web pertama kali akan menampilkan halaman Home,
p-ISSN : 1858-3911, e-ISSN : 2614-5405

https://journal.uniku.ac.id/index.php/ilkom

dimana pada halaman tersebut pengguna dapat melihat preview dari produk pakaian yang tersedia. Apabila pengguna belum melakukan login maka menu utama pada halaman tersebut akan menampilkan beranda, cara pembelian, sejarah perusahaan, kontak kami, struktur organisasi, kategori, $\log$ in, dan tentang.

\section{Form Login}

Apabila pelanggan telah memiliki akun melalui proses registrasi maka langkah selanjutnya adalah melakukan login akses. Pada form login terdiri dari form username dan password yang harus diisi sesuai dengan informasi pada saat pendaftaran oleh admin. Lebih jelas mengenai tampilan form login dapat dilihat pada gambar 6 berikut ini.

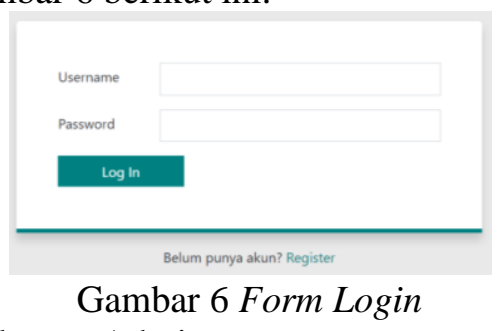

Halaman Admin

Halaman admin digunakan oleh hak akses admin untuk mengontrol berbagai komponen penyusun sistem yang digunakan. Pada halaman admin terdiri dari beberapa modul yang berintegrasi diantaranya adalah Kategori Produk, Produk, Produk Poin, Lihat Order Masuk, Lihat Order Poin Masuk, Promo Poin, Ongkos Kirim, Jasa Pengiriman. Untuk lebih jelasnya dapat dilihat pada uraian berikut ini.

Halaman Awal Admin

Pada halaman ini bagian admin akan ditampilkan modul-modul yang dapat di update seputar produk yang ada pada Distro Chanel.

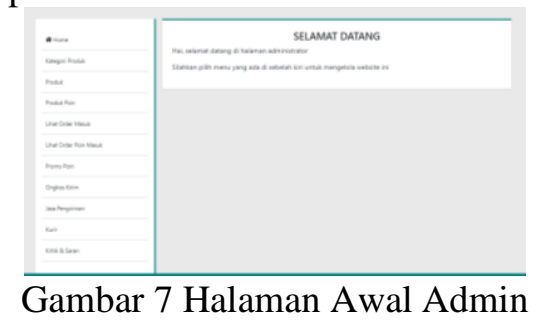

Halaman Laporan 


\section{JURNAL NUANSA INFORMATIKA}

Volume 14 Nomor 1, Januari 2020

Halaman Laporan Transaksi

Manajer distro dapat memperoleh laporan lengkap mengenai berbagai aktifitas transaksi yang berlangsung dalam bentuk format data pdf.

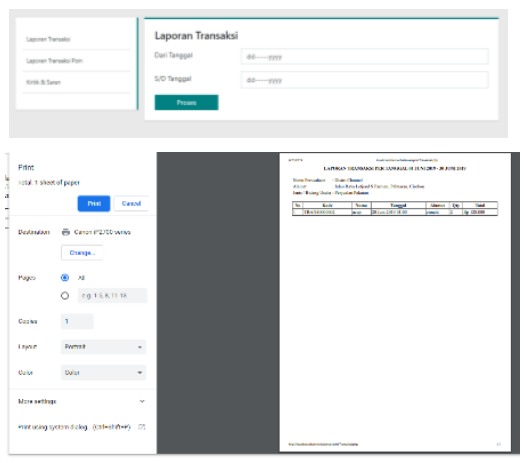

Gambar 8 Laporan Transaksi

Halaman Laporan Transaksi Poin

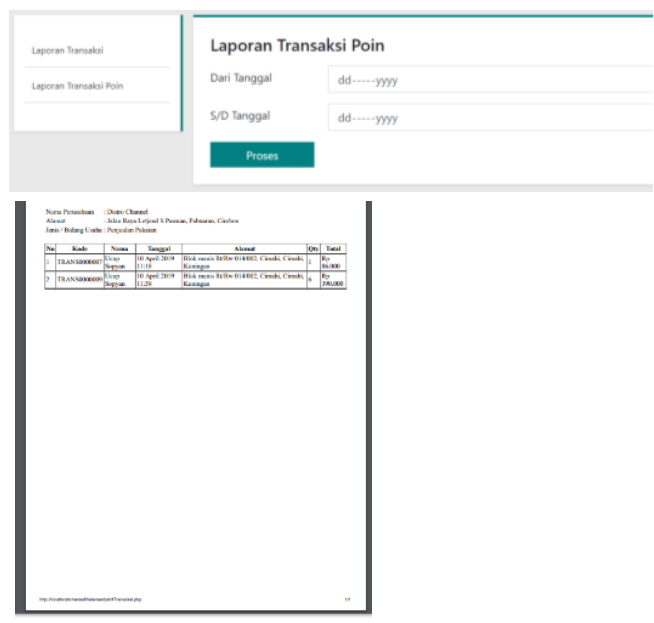

Gambar 9 Halaman Laporan Trannsaksi Poin

\section{KESIMPULAN}

Setelah melalui berbagai tahapan perancangan pengujian serta implementasi CRM pada sistem informasi penjualan pakaian pada Distro Channel Cirebon, maka penulis mencoba mengemukakan beberapa kesimpulan dalam penelitian ini ialah implementasi CRM pada proses penjualan pakaian di Distro Channel Cirebon meningkatkan kualitas pelayanan sehingga mampu meningkatkan loyalitas pelanggan. Sistem ini dapat mempersingkat waktu pelayanan dan memberikan kemudahan baik konsumen maupun Distro. Sistem ini mendorong efisiensi waktu dan biaya dalam proses pengelolaan oleh pihak managemen maupun oleh pihak distro.
p-ISSN : 1858-3911, e-ISSN : 2614-5405

https://journal.uniku.ac.id/index.php/ilkom

Ruang lingkup dalam proses pemasaran yang lebih luas.

\section{SARAN}

Melihat dari hasil kesimpulan diatas maka penulis memberikan saran, diantaranya adalah:

Perlu adanya peningkatan kualitas interface yang lebih spesifik dengan design yang lebih ramah pengguna sehingga setiap kalangan dapat mempergunakannya dengan mudah.

Sistem dapat dikembangkan lebih luas melengkapi fitur yang sudah ada menjadi lebih lengkap sesuai kebutuhan administrasi bisnis.

Perlu adanya peningkatan pada sistem pembayaran sehingga lebih realtime.

\section{DAFTAR PUSTAKA}

[1] Sommerville, Ian. 2011. Software Enginering (Rekayasa Perangkat Lunak). Jakarta: Erlangga.

[2] Buttle. (2007). Customer Relationship Management: Concept and tools. Malang: Bayumedia Publishing.

[3] Gunasekaran and kobu, 2009. Modeling and Analysiss of Business Process Reengineering, vol.40. 